\title{
Institutional Review Board Independent Ethics Committee Report
}

National Cancer Institute

\section{Source}

National Cancer Institute. Institutional Review Board Independent Ethics Committee

Report. NCI Thesaurus. Code C115584.

Records sent to the Institutional Review Board (IRB) or Independent ethics committee (IEC) at regular intervals, which provides information and updates about a clinical trial. 